\title{
Judicial Analysis of the Powers and Functions of the Administrative Tribunals
}

\author{
Sanjay Gupta* and Smriti Sharma ${ }^{\dagger}$
}

\begin{abstract}
Administrative tribunals are adjudicating bodies established to relieve the traditional courts from the ever mounting pressure of litigation. This paper makes an analysis of the powers and functions of the administrative tribunals as laid down by the judiciary. A series of case laws are examined at length which debate the nature of the functions of the tribunals and also elucidate the importance of tribunals in dispensation of justice.
\end{abstract}

Keywords: Constitution, Court, Justice, Litigation, Tribunal

\section{Introduction}

Administrative Tribunals have existed in a rudimentary form for quite some time. In 1958, in order to relieve the courts, from the burden of service litigation, the Law Commission recommended the establishment of tribunals consisting of judicial and administrative members to decide service matters. ${ }^{1}$ The Central Government appointed a committee under the chairmanship of Justice J.C. Shah of the Supreme Count of India in 1969, which also

\footnotetext{
* Associate Professor, Department of Law, University of Jammu, Jammu, India; sanjaytutu08@yahoo.in.

${ }^{\dagger}$ Research Scholar, Department of Law, University of Jammu, Jammu. India.

1 Law Commission of India, XIV REPORT OF REFORM OF JUDICIAL ADMINISTRATION (1958), available at http:/ lawcommissionofindia.nic.in/ 1-50/Report14Vol1.pdf.
} 
made similar recommendations. ${ }^{2}$ In 1975, Swaran Singh Committee again recommended the setting up of service tribunals. ${ }^{3}$ The idea of setting up of service tribunals is to save the courts from the avalanche of writ petitions and appeals in service matters. This also found favour with the Supreme Court of India in K.K. Dutta v. Union of India. ${ }^{4}$ It was against this backdrop that the Parliament passed the Constitution (42nd Amendment) Act, 1976 which added Part XIV - A to the Constitution. Article 323-A enabled Parliament to constitute Administrative tribunals for dealing with certain matters like recruitment and conditions of service of persons appointed to public services and posts in connection with the affairs of union or of any state or of any local or other authority within the territory of India or under the control of the Government of India or of any corporation owned or controlled by the government; while Article 323-B empowers the appropriate legislature i.e. both the Parliament and the State legislatures to establish tribunals for the adjudication or trial of any disputes, complaints or offences with respect to matters like levy, assessment, collection and enforcement of any tax, ceiling on urban property, elections to the Houses of central or state legislatures and any other matter. Parliament was further empowered to prescribe by law the jurisdiction, power, authority and procedure of such tribunals and also to exclude the jurisdiction of all the courts except that of the Supreme Court under Article 136. ${ }^{5}$ Considering these provisions of the Constitution, Parliament enacted Administrative Tribunals Act 1985 which came into effect on November 1, 1985 for the establishment of administrative tribunals for deciding service disputes of civil servants of the centre as well as of the states.

\footnotetext{
2 Law Commission of India, 215 REPORT L. CHANDRA KUMAR BE REVISITED By LARGER BENCH OF SuPREME COURT SHAH COMMISSION REPORT (1977), available at http:/ / lawcommissionofindia.nic.in/reports/report215.pdf.

${ }^{3} \mathrm{Id}$.

${ }^{4}$ A.I.R. 1980 S.C. 2056.

5 CONSTITUTION OF INDiA, art. 323-A (2) (d), 323-B (3) (d).
} 


\section{Service Tribunals}

The Central Administrative Tribunal is empowered to exercise all the jurisdiction, power and authority exercisable immediately by all courts except the Supreme Court. ${ }^{6}$ The Act does not, however apply to the employees of the state of Jammu and Kashmir, any member of the Naval, Military or Air Force or any other Armed Forces of the Union, officers and servants of the Supreme Court and High Courts, Secretarial Staff of the House of People, Council of States and state legislative assemblies and councils. ${ }^{7}$ Central Industrial Security Force and Cantonment Board also do not fall under the jurisdiction of Central Administrative Tribunal.

In adjudicating disputes, the tribunals are not bound by the procedure laid down by the Code of Civil Procedure 8 but are guided by the principles of natural justice. The tribunals are vested with the same powers as of the civil courts under the Code of Civil Procedure 1908. ${ }^{9}$ They may summon and enforce the attendance of any witness for examining under oath. They can receive evidence on affidavit and can examine the witnesses. The tribunals are empowered to review their own decisions and in all procedural matters including the fixing of places, time of inquiry. The tribunals in order to regulate their own procedure are required to conform to specific rules framed by the Central Government and to the principles of natural justice. ${ }^{10}$

In relation to service matters, the jurisdiction, power and authority is vested with the Administrative Tribunals to the exclusion of various courts. Before the establishment of the Administrative Tribunal for service matters, the suits for enforcement of any civil right were entertained by the civil court. ${ }^{11}$ The jurisdiction of these courts is now barred by the Administrative Tribunal Act 1985.12 Furthermore, there was a provision initially for the exclusion of all

\footnotetext{
6 See The Administrative Tribunal Act, 1985 § 12(1).

7 The Administrative Tribunal Act, 1985 §§ 1 (2) (b), 2.

8 The Administrative Tribunal Act, 1985 § 22.

9 The Administrative Tribunal Act, 1985 § 22 (3).

10 The Administrative Tribunal Act, $1985 \S 35$.

11 Code of Civil Procedure, 1908 § 9.

12 The Administrative Tribunal Act, 1985 § 29.
} 
the courts except the Supreme Court under Article 136 of the Constitution. ${ }^{13}$ This provision has been amended ${ }^{14}$ after the case of Sampath Kumar v. Union of India ${ }^{15}$ and the words 'no court except':

a) The Supreme Court or;

b) Any industrial tribunal, labour court or other authority constituted under the Industrial Dispute Act, 1947 or any other corresponding law for the time being in force,

have been inserted.

The jurisdiction of the High Court under Articles 226 and 227 has also been barred by the provision of the enactment. ${ }^{16}$ It cannot be said that civil servants don not possess the right of judicial review through the establishment of Administrative Tribunal by ousting the jurisdiction of the High Court. The change made is that the employees shall first go to Administrative Tribunal and thereafter to the Supreme Court.

According to the Act, the tribunal is empowered to pronounce judgment in civil proceedings which would be final ${ }^{17}$ except in cases where an appeal under Article 136 of the Constitution to the Supreme Court is preferred.

\section{Judicial Analysis of the Powers and Functions of the Administrative Tribunals}

Since the Administrative Tribunal Act, 1985 provides appeal by special leave to the Supreme Court, it is pertinent to explore the contours of Article 136. Article 136 is a special provision and covers generally the cases, which do not fall under Articles 132 to 134. This provision of the Constitution is not subjected to certification by the High Courts as a fit case of appeal. Therefore, it is a rare provision which can be swung into action to maintain the spirit of the Constitution and to prevent the miscarriage of justice.

${ }^{13}$ The Administrative Tribunal (Amendment) Act, 1986.

14 The Administrative Tribunal (Amendment) Act, 1986 § 28.

${ }^{15}$ A.I.R. 1987 S.C. 386.

16 A.I.R. 1950 S.C. 188.

17 The Administrative Tribunal Act, 1985 § 30. 
Article 136 confers discretion on the Supreme Court to grant special leave to appeal before itself, from only judgment, determination, sentence, order passed or made by any court or tribunal in any cause or matter. Indeed, the judgment of the courts and Tribunals can be appealed to the Supreme Court under the provisions of this Article. However, what is a tribunal, is a subject matter of debate. The meaning of the word tribunal as interpreted by the Supreme Court in various appeals filed under the Article 136 of the Constitution presents a vivid picture as to the meaning of the word tribunal.

In Bharat Bank v. Employees of Bharat Bank, ${ }^{18}$ the five judge bench while deciding the fate of appeal considered the question whether the Supreme Court could entertain an appeal under Article 136 against an award of an industrial tribunal. The minority comprising Mukherjee J., expressed the view that the tribunal's function was merely an extended form of the process of collective bargaining and was more akin to administrative rather than judicial functions. The Supreme Court could not grant special leave to appeal from an award of industrial tribunal, because of the minority judgment. Mahajan J., opined that the industrial tribunal has all the necessary attributes of a court of justice. It discharges no other function except that of adjudicating a dispute and such a tribunal could be characterized as a quasi-judicial body because it is outside the regular judicial hierarchy. Nevertheless, it discharges functions, which are basically judicial in nature. Accordingly, it was held that the Supreme Court could grant special leave to appeal under Article 136 against an award of an industrial tribunal. Kania, C.J. opined that even though the Supreme Court has jurisdiction to grant leave to appeal from a decision given by an industrial tribunal, the Supreme Court will be very reluctant to entertain the application for leave to appeal. The apex court further opined that the word 'tribunal' in the Article 136, meant a tribunal adorned with similar trappings as a court and performing functions which cannot but be regarded as judicial.

18 The Administrative Tribunal Act, $1985 \S 28$. 
In JEK Iron and Steel Co. Ltd. v. Iron and Steel Mazdoor Union, Kanpur ${ }^{19}$, the question regarding whether the scope and authority of adjudicator and state industrial tribunal is similar to the powers of the civil court. The apex court stated howsoever wide their powers are, these tribunals are not absolute though they are not courts in the strict sense of the term. They have to discharge quasi judicial functions and as such are subject to the over-riding jurisdiction of the Supreme Court under Article 136 of the Constitution. Under the Constitution, the ultimate authority is given to the higher courts to restrain all exercise of absolute and arbitrary powers, not only by the executive and by officials and lesser tribunals, but also by the legislatures and even by the Parliament itself.

Further in Harinagar Sugar Mills v. Shyam Sunder, ${ }^{20}$ it was provided that the attributes of a court is the part of a tribunal set up by a state under its Constitution to exercise the judicial power of the state i.e., the power to decide controversies between its subjects or between itself and its subjects - to uphold rights and to punish wrongs.

Moreover, a tribunal must be recognized by the law as a 'court', and mere exercise of functions in a judicial manner is not enough. It must exercise the power to decide by reason of the sanction of law and not by the voluntary submissions of the parties to its jurisdiction and like a court, must determine the controversy objectively and impartially.

The ambit of the word 'court' is wider than 'tribunal'. All courts are tribunals, but all tribunals are not courts. The expression tribunal means seat of judge, or a court of justice. ${ }^{21}$ The necessary attribute is that it can give a final judgment between two parties, which carries legal sanction by its own force. That the word 'tribunal' in juxtaposition to the word 'court' could only mean a tribunal which exercised judicial functions of the state and did not include within its ambit a tribunal which had quasi-judicial or administrative powers. It was finally said that by the use of word 'tribunal' in

\footnotetext{
19 A.I.R. 1956 S.C. 231.

${ }^{20}$ A.I.R. 1961 S.C. 1669.

21 Durga Shankar Mehta v. Thakur Raghuraj Singh and Ors., A.I.R. 1954 S.C. 520 .
} 
Article 136, the intention was to give the similar meaning as 'court'.22

However in Durga Shanker's Case ${ }^{23}$ it was pointed out that the expression 'tribunal' as used in Article 136 of the Constitution does not mean the same thing as 'court' but includes within its ambit, all adjudicating bodies, provided they are constituted by the state and are invested with judicial as distinguished from purely administrative or executive functions ${ }^{24}$.

Further in Engineering Mazdoor Sabha v. Hind Cycles Ltd. ${ }^{25}$ the apex court observed that for invoking Article 136 (1) two conditions must be satisfied:

i. the act complained against must have the character of a judicial or quasi-judicial act as distinguished from a mere executive or administrative act; and

ii. the authority whose act is complained against must be a court or a tribunal.

Furthermore, the apex court distinguishing a 'tribunal' from a court stated that the expression 'court' in the technical sense is a tribunal constituted by the state as a part of ordinary hierarchy of courts, which are invested with state's inherent judicial powers. A tribunal as distinguished from a court, exercises a judicial power and decides matters brought before it judicially or quasi-judicially, but does not constitute a court in the technical sense. The tribunal, according to the dictionary meaning, is a 'seat of justice'; and in the discharge of its functions, it shares some of the characteristics of the court. The domestic tribunal appointed in the departmental proceedings as well as purely administrative tribunals are outside the scope of Article 136 (1). Tribunals which are contemplated by Article 136 (1), are clothed with some of the powers of the court.

\footnotetext{
22 Bharat Bank v. Employees of Bharat Bank A.I.R. 1950 S.C. 188.

${ }^{23}$ Durga Shankar Mehta v. Thakur Raghuraj Singh and Ors., A.I.R. 1954 SC 520.

${ }^{24}$ Durga Shankar Mehta v. Thakur Raghuraj Singh A.I.R. 1954 S.C. 520.

25 A.I.R. 1963 S.C. 874; See Jaswant Sugar Mills Ltd., Meerut v. Lakshmi Chand A.I.R. 1963 S.C. 677,Indo-China Steam Navigation Co. Ltd. v. Jasjit Singh A.I.R. 1964 S.C. 1140.
} 
They can compel the witnesses to appear; they can administer oath; they are required to follow certain rules and procedure; the proceedings before them are required to comply with rules of natural justice; they are not be bound by the strict and technical rules of evidence but nevertheless they must decide on evidence adduced before them; they must not be bound by the other technical rules of law, but their decisions must nevertheless be consistent with the general principles of law. The procedural rules which regulate the proceedings before the tribunal and the powers conferred on them in dealing with matters brought before them are sometimes described as 'trapping of a court'. The basic and essential condition that makes an authority or a body, a tribunal under Article 136 is that it should be constituted by the state and should be invested with the state's inherent judicial power.

In Durga Shankar Mehta v. Raghuraj Singh,26the apex court opined that the expression 'tribunal' includes within its ambit, all adjudicating bodies, provided they are constituted by the state and are invested with judicial functions. The powers given by Article 136 of the Constitution are in the nature of special or residuary powers and vests in the Supreme Court a plenary jurisdiction in the matter of entertaining appeals, by granting of special leave against any kind of judgment or order made by a court or tribunal.

Moreover, the apex court has also observed that its scope and power under Article 136 of the Constitution vis-à-vis awards of tribunals is not that of a regular court of appeal against orders of tribunals. Article 136 confers a discretionary power on the Supreme Court to grant Special leave to appeal from the order of any tribunal in the territory of India. ${ }^{27}$

Moreover, the Supreme Court expects the tribunals to record speaking order even while summarily dismissing the appeals. The condition of giving reason is only attached to an order made by the government when it functions judicially as a tribunal in a

26 See Dhakeshwari Cotton Mills Ltd v. Commissioner of Income Tax, West Bengal A.I.R 1955 S.C. 65;

$\mathrm{M} / \mathrm{s}$ Bengal Chemical and Pharmaceutical Works Ltd. v. Their Employees A.I.R. 1959 S.C. 633.

27 Hindustan Antibiotics Ltd. v. Workmen A.I.R. 1567 S.C. 948. 
comparatively small number of matters and not in regard to other administrative orders it passes. The condition to give reason introduces clarity and exclude or at any rate minimizes arbitrariness. ${ }^{28}$

Further, it was opined that the principles of natural justice requires a quasi-judicial tribunal not make a decision adverse to a party without giving him an effective opportunity of meeting any relevant allegation made against him but that depends on the facts of each case and it is in the discretion of the tribunal. ${ }^{29}$

In reference to appeals from tax tribunals, it is observed that save in exceptional and special circumstances, the Supreme Court would not exercise its power under Article 136 in such a way as to bypass the High Court by entertaining an appeal direct from the order of Income Tax Appellate Tribunal and thereby ignore the decision given by the High Court. ${ }^{30}$

In L. Chandra Kumar v. Union of India, ${ }^{31}$ the apex court opined that the power of judicial review over legislative action vested in the High Court under Article 226 and in the Supreme Court under Article 32 of the Constitution is an integral and essential feature of the Constitution, constituting part of its basic structure. Further, it was opined that the tribunals are competent to hear matters where the vires of statutory provisions are questioned. However, in discharging this duty, they cannot act as substitutes for the High Courts and the Supreme Court, which have, under the constitutional set up, been specifically entrusted with such an obligation. Their function in this respect is only supplementary and all such decisions of the tribunal will be subject to scrutiny before a division bench of the respective High Court. The tribunals will consequently also have the power to test the vires of subordinate legislations and rules. However, the power of the tribunals shall be subjected to an exception that they shall not entertain any question regarding the vires of their parent statutes following the settled

${ }^{28}$ Madhya Pradesh Industries Ltd. v. Union of India A.I.R. 1966 S.C. 671.

${ }^{29}$ Madhya Pradesh Industries Ltd. v. Union of India A.I.R. 1966 S.C. 671.

30 Commissioner of Income Tax, Bombay v. Lakhiram Ramdas A.I.R. 1967 S.C. 338.

31 A.I.R. 1997 S.C. 1125. 
principle that a tribunal which is a creation of a legislation cannot declare the same to be unconstitutional. In such cases alone, the concerned High Court may be approached directly. All other decisions of the tribunals will also be subject to scrutiny before a Division Bench of their respective High Court.

Thus, through this case, the apex court tried to save the jurisdiction of constitutional courts from encroachment by legislature by invoking the doctrine of 'basic features of the Constitution'.

By comparing L. Chandra's Case 32 with Sampat Kumar's Case 33 , the Supreme Court held that Sampat Kumar's Case was decided against the background, that the litigation before the High Courts had increased in an unprecedented manner and therefore, alternative inquisitional mechanism was necessary to remedy the situation. But it is self evident and a widely acknowledged truth that the tribunals have not performed well, hence drastic measures are necessary in order to elevate their standard by ensuring that they stand up to constitutional scrutiny. Further, the court held that because the constitutional safeguards which ensure the independence of the judges of the Supreme Court and the High Courts are not available to the members of the tribunals, hence they cannot be considered full and effective substitute for the superior judiciary in discharging the function of constitutional interpretation. Against this backdrop, the court came to the conclusion that Administrative Tribunals cannot perform a substitutional role to the High Court, it can only be supplemental.

Further the Supreme Court in State of T.N. v. S. Thangavel, 34 held that members of the tribunal are not judges and their order is not a judgment or decree under Section 2 (9) of the Civil Procedure Code 1908. At best their statements can be construed to be only orders for the purpose of decision arrived at by the tribunal under the Administrative Tribunal Act 1985.

Even though the judgment in the above cases does not ipso facto apply to the Constitution of Jammu and Kashmir, but the ratio of the case applies to the exercise of jurisdiction by the Jammu and

\footnotetext{
32 A.I.R. 1997 S.C. 1125.

33 A.I.R. 1987 S.C. 386.

34 (1997) 2 SCC 349.
} 
Kashmir High Court. Thus, in Kendriya Vidyalaya Sangthan v. Subash Sharma, ${ }^{35}$ it was held that the central government employees working in the State of Jammu and Kashmir cannot by pass the jurisdiction of the Central Administrative Tribunal. It has an exclusive jurisdiction, as a court of first instance, in relation to service matters concerning employees of the Kendriya Vidyalaya posted in the State of Jammu and Kashmir.

\section{Administrative Tribunal and the Doctrine of Stare Decisis}

The 'doctrine of precedent' applies to the Administrative Tribunals as well. The court held that whenever an application under Section 19 of the Administrative Tribunal Act 1985 is filed which involves a question already concluded by an earlier decision, the tribunal must take into account that decision as a precedent and decide accordingly. If the tribunal dissents then the matter must be referred to a larger bench. ${ }^{36}$

\section{Conclusion}

The basic purpose behind the establishment of administrative tribunals is to provide expeditious justice to the civil servants, which is not available under the traditional system. The apex court has maintained that before availing the appellate powers under Article 136, the person must exhaust the statutory remedies available to him. Even this is a self imposed regulation of the apex court in order to check the multiplicity of the proceedings before the apex court. The above stance can be relaxed by the Supreme Court if special circumstances justified as is highlighted in Chandi Prasad Chokhani v. State of Bihar. ${ }^{37}$

It can thus be seen that the apex court can not only entertain the cases from the regular courts, but also the cases determined by all adjudicating bodies invested with judicial functions. It does not matter that the statute empowering such adjudicating bodies with power of adjudication does not provide for further appeals and

35 (2002) 4 S.C.C. 145.

${ }^{36}$ K. Ajit Babu v. Union of India (1997) 6 S.C.C. 473.

37 A.I.R. 1961 S.C. 1708. 
confers conclusive finality to the decisions of the tribunals. ${ }^{38}$ The special leave to appeal can be granted by the apex court if the adjudicating bodies including tribunals do not observe the principles of natural justice especially in cases where no reason for decision has been provided by the adjudicating authorities. Moreover, appeal by special leave shall be allowed by the Supreme Court only in cases where there is likelihood of substantial and grave injustice.

Thus, Administrative Tribunals will go a long way as a supplementary dispute resolution mechanism and help in minimizing the number of cases pending before the court.

${ }^{38}$ Durga Shankar Mehta v. Raghuraj Singh A.I.R. 1954 S.C. 520. 